\title{
Profil Pubertas dan Pertumbuhan Linear pada Hiperplasia Adrenal Kongenital dalam Pengobatan Serial Kasus
}

\author{
Nurul Iman Nilam Sari, Bambang Tridjadja, Nastiti Kaswandani, Damayanti Rusli Sjarif, \\ Sukman Tulus Putra, Hartono Gunardi \\ Departemen Ilmu Kesehatan Anak Fakultas Kedokteran Universitas Indonesia/Rumah Sakit Dr. Cipto \\ Mangunkusumo, Jakarta
}

\begin{abstract}
Latar belakang. Terapi yang adekuat pada hiperplasia adrenal kongenital (HAK) diharapkan dapat menghasilkan perkembangan pubertas dan pertumbuhan linear yang optimal. Saat ini, di Indonesia, belum ada data profil pubertas dan pertumbuhan linear penderita HAK yang sedang menjalani terapi.

Tujuan. Mengetahui profil pubertas dan pertumbuhan linear pada HAK di Indonesia yang sedang menjalani terapi.

Metode. Studi serial kasus terhadap 14 kasus HAK yang memasuki masa pubertas di Departemen Ilmu Kesehatan Anak Rumah Sakit Cipto Mangunkusumo Jakarta selama bulan November 2012 hingga April 2013. Pencatatan data berisi anamnesis, pemeriksaan fisis, pemeriksaan laboratorium, dan radiologi bone age.

Hasil. Hasil penelitian ini merupakan riset pendahuluan (preliminary research) terhadap 14 kasus HAK. Mayoritas subjek adalah perempuan, berusia di atas 8 tahun, HAK tipe Salt-Wasting (SW), dan terdiagnosis sejak kurang dari satu tahun. Tujuh dari 14 subjek mengalami obesitas. Undertreatment terjadi pada 11/14 subjek memiliki bone age accelerated dengan perhitungan tinggi badan dewasa yang pendek. Tiga belas subjek sudah pubertas dan 10/14 subjek mengalami pubertas prekoks. Rekomendasi dosis glukokortikoid yang diberikan (median 18,12 mg/m²/hari) dengan median durasi terapi 8,1 tahun. Kontrol metabolik dengan menggunakan parameter $17-\mathrm{OHP}$ bervariasi pada rentang 0,2-876 nmol/L (rerata $166,9 \mathrm{nmol} / \mathrm{L}$ ).

Kesimpulan. Sebagian besar subjek mendapatkan undertreatment sehingga memiliki bone age accelerated dengan estimasi tinggi badan dewasa pendek. Pubertas prekoks dialami oleh sebagian besar subjek. Pemberian glukokortikoid dengan dosis yang direkomendasikan. Ditemukan ketidakteraturan pengobatan dan pemantauan yang buruk. Sari Pediatri 2015;16(5):356-64.
\end{abstract}

Kata kunci: hiperplasia adrenal kongenital, pubertas, pertumbuhan linear, terapi

\footnotetext{
Alamat korespondensi:

Dr. Nurul Iman Nilam Sari. Departemen Ilmu Kesehatan Anak, Fakultas Kedokteran Universitas Indonesia-Rumah Sakit Cipto Mangunkusumo. J1. Salemba Raya No. 6, Jakarta Pusat 10430. Telp. (021) 3907742, Fax. (021) 3907743
}

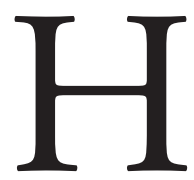
iperplasia adrenal kongenital (HAK) merupakan kelainan genetik yang membutuhkan terapi substitusi glukokortikoid seumur hidup dan mineralokorti- 
koid jangka panjang. ${ }^{1-3}$ Pada pasien HAK di Divisi Endokrinologi Departemen Ilmu Kesehatan Anak Fakultas Kedokteran Universitas Indonesia-Rumah Sakit Cipto Mangunkusumo, terapi substitusi glukokortikoid yang diberikan adalah hidrokortison dosis $10-20 \mathrm{mg} / \mathrm{m}^{2} /$ hari dibagi menjadi 2 atau 3 dosis. ${ }^{4}$ Dosis tersebut berada dalam rentang dosis efektif untuk mengontrol kadar hormon steroid yang memungkinkan pertumbuhan linear dan perkembangan pubertas normal. ${ }^{3,5}$ Terapi yang diberikan dapat memberikan luaran undertreatment, optimal dan overtreatment. ${ }^{2}$ Penelitian-penelitian sebelumnya melaporkan bahwa pasien HAK yang mendapat terapi steroid jangka panjang dapat memengaruhi perkembangan pubertas dan pertumbuhan linear dengan hasil yang bervariasi. ${ }^{6}$ Terapi yang adekuat diharapkan dapat menghasilkan pertumbuhan linear, perkembangan pubertas, dan fertilitas yang optimal pada HAK. ${ }^{3,7}$

Saat paling penting untuk memantau terapi pada HAK adalah setelah 2 tahun pertama pemberian terapi dan pada saat pubertas. ${ }^{8}$ Efektivitas terapi dinilai dari tinggi badan, usia tulang, status pubertas, kadar 17-hidroksi progesteron (17-OHP), dan testosteron dalam serum. ${ }^{3,8}$ Pengetahuan tentang hal tersebut diharapkan dapat dijadikan acuan untuk memperbaiki prosedur tata laksana HAK untuk mencapai pengobatan yang optimal. Penelitian ini bertujuan untuk menampilkan profil pubertas dan pertumbuhan linear penderita HAK di Indonesia dalam menjalani terapi.

\section{Metode}

Studi deskriptif serial kasus dilakukan terhadap pasien HAK yang memasuki masa pubertas. Penelitian dilakukan di Poliklinik Endokrinologi Departemen IKA RSCM dan pertemuan KAHAKI (Komunitas Keluarga Hiperplasia Adrenal Kongenital Indonesia) selama bulan November 2012 hingga April 2013. Pemilihan subjek dilakukan secara consecutive sampling.

Kriteria inklusi adalah pasien HAK dan telah mendapat pengobatan hormonal minimal 2 tahun. Pasien HAK perempuan yang telah memasuki masa pubertas adalah anak berusia 8-13 tahun dan ditandai dengan pertumbuhan payudara. Sebaliknya, pasien HAK laki-laki adalah anak berusia 9-14 tahun ditandai dengan pertambahan volume testis atau memiliki tanda seks sekunder atau pubertas sebelum usia 8 tahun pada anak perempuan dan sebelum usia 9 tahun pada anak laki-laki. Kriteria eksklusi adalah pasien HAK yang menderita penyakit lain dan sedang diterapi dengan steroid jangka panjang segingga memengaruhi pubertas, misalnya pasien dengan sindrom nefrotik, juvenille rheumatoid arthritis.

Data yang dikumpulkan adalah identitas, riwayat perjalanan penyakit, riwayat penyakit dahulu, riwayat penyakit dalam keluarga, riwayat kelahiran, riwayat nutrisi, pemeriksaan fisis (tanda vital, status gizi dan antropometri, indeks masa tubuh, status generalis, dan status pubertas), pemeriksaan kadar hormon seks (FSH, LH, estradiol dan testosteron), kadar 17$\mathrm{OH}$, dan bone age. Data penelitian diolah dengan menggunakan statistical package for the social sciences (SPSS) versi 17.

Undertreatment adalah pengobatan steroid pada pasien HAK yang tidak optimal atau ketidakteraturan pemakaian obat yang disebabkan karena pemberian dosis yang kurang (dosis hidrokortison $<10 \mathrm{mg} /$ $\mathrm{m}^{2} /$ hari). Terapi optimal adalah pengobataan steroid pada pasien HAK dengan dosis yang tepat dan diberikan secara teratur dengan dosis hidrokortison $10-20 \mathrm{mg} / \mathrm{m}^{2} /$ hari. Overtreatment jika pengobatan steroid berlebihan, yaitu dosis hidrokortison $>20 \mathrm{mg} /$ $\mathrm{m}^{2} /$ hari dalam jangka panjang. ${ }^{2}$ Keteraturan terapi adalah perilaku pasien yang mentaati semua nasihat dan petunjuk yang dianjurkan oleh kalangan tenaga medis, seperti dokter dan apoteker; untuk mencapai tujuan pengobatan.

\section{Hasil}

Subjek penelitian yang memenuhi kriteria inklusi adalah 14 anak. Mayoritas berjenis kelamin perempuan dengan rasio perempuan:laki-laki 3,6:1 dan median usia 9,1 tahun (7,1 tahun-13,1 tahun). Tipe salt wasting (SW) 10 subjek, tipe simple virilizing (SV) 3 subjek dan non klasik 1 subjek. Delapan subjek didiagnosis pada usia $\leq 1$ tahun dan 6 subjek didiagnosis saat berusia $>1$ tahun. Gambaran klinis subjek pada saat awal gejala adalah genitalia ambigu (10/14), krisis adrenal (9/14), hiperpigmentasi kulit (8/14) dan hirsutisme (8/14) (Tabel 1).

Tinggi badan subjek penelitian sebagian besar normal, terletak pada P3-97 dan satu subjek memiliki tinggi badan $<$ P3, kurva CDC 2000 (terlampir pada 
Tabel 1. Karakteristik klinis subjek penelitian $(\mathrm{n}=14)$

\begin{tabular}{|c|c|c|}
\hline Karakteristik klinis & & $\mathrm{n}$ \\
\hline \multicolumn{3}{|l|}{ Jenis kelamin } \\
\hline Laki-laki & & 3 \\
\hline Perempuan & & 11 \\
\hline \multicolumn{3}{|l|}{ Usia (tahun) } \\
\hline \multirow[t]{2}{*}{ Laki-laki } & & 1 \\
\hline & & 2 \\
\hline \multirow{2}{*}{\multicolumn{2}{|c|}{$\begin{aligned} \text { Perempuan } & <8 \\
& 8-13\end{aligned}$}} & 2 \\
\hline & & 9 \\
\hline \multicolumn{3}{|l|}{ Tipe HAK } \\
\hline SW & & 10 \\
\hline SV & & 3 \\
\hline NK & & 1 \\
\hline \multicolumn{3}{|c|}{ Usia saat diagnosis dan tipe HAK } \\
\hline$\leq 1$ bulan & $\mathrm{SW}^{*}$ & 4 \\
\hline 1 bulan - 1 tahun & SW & 4 \\
\hline \multirow[t]{3}{*}{$>1$ tahun } & SW & 2 \\
\hline & SV & 3 \\
\hline & $\mathrm{NK}^{* *}$ & 1 \\
\hline \multicolumn{3}{|c|}{ Genitalia ambigu sejak lahir } \\
\hline \multicolumn{2}{|l|}{$\mathrm{Ya}$} & 10 \\
\hline \multicolumn{2}{|l|}{ Tidak } & 4 \\
\hline \multicolumn{3}{|l|}{ Tinggi badan } \\
\hline \multicolumn{2}{|l|}{ Normal (P3-P97) } & 13 \\
\hline \multicolumn{2}{|l|}{ Pendek $(<\mathrm{P} 3)$} & 1 \\
\hline \multicolumn{3}{|l|}{ Status nutrisi IMT } \\
\hline \multicolumn{2}{|l|}{ Baik (P5-P85) } & 5 \\
\hline \multicolumn{2}{|l|}{ Lebih $(\geq$ P85-<P95) } & 2 \\
\hline \multicolumn{2}{|l|}{ Obesitas ( $\geq$ P95) } & 7 \\
\hline \multicolumn{3}{|l|}{ Status pubertas } \\
\hline Prekoks & & 10 \\
\hline Sesuai & & 3 \\
\hline Belum & & 1 \\
\hline
\end{tabular}

${ }^{*} \mathrm{SW}=$ salt wasting, ${ }^{* *} \mathrm{NK}=$ non-klasik yang berlebih (>100\%). Persentase kebutuhan kalori yang tercukupi berdasarkan analisis diet menunjukkan median 121\% (79\%-149\%). Seluruh subjek memiliki aktivitas fisis yang tidak aktif. Sepuluh subjek mengalami pubertas prekoks dan 3 subjek mengalami pubertas sesuai dengan usianya. Pubertas prekoks terdapat pada 7 subjek perempuan dan 3 subjek lakilaki. Satu subjek belum pubertas dan tidak ada subjek yang mengalami keterlambatan pubertas.

Gambaran pubertas penderita HAK berdasarkan Tanner menunjukkan keadaan prekoks pada 10 subjek. Tanda pubertas telah muncul lebih dini berdasarkan diagram pertumbuhan fisik anak perempuan dan laki-laki selama pubertas (terlampir pada Gambar 3). Tiga belas subjek telah pubertas, 8 dari 14 subjek telah mengalami menarche (median 8 tahun, rentang 6-12 tahun) atau spermache (median 7 tahun, rentang 6-9 tahun). Satu subjek, yaitu subjek 11, belum mengalami pubertas (A1M1P1). Secara umum, gambaran hormon seks subjek penelitian berada pada nilai normal sesuai usia pubertas atau memiliki nilai yang lebih tinggi dari rentang prepubertas. Kesepuluh subjek prekoks sesuai dengan undertreatment, memiliki kadar 17-OHP yang tinggi, dan bone age accelerated. Karakteristik hormon subjek dan rerata dosis glukokortikoid pada subjek dalam kelompok salt wasting tertera pada tabel terlampir. Sementara itu, rerata tinggi badan berdasarkan skor standar deviasi (SDS) terlampir pada Gambar 4.

Terapi glukokortikoid telah diberikan sejak tahun pertama kelahiran pada 9 subjek, sedangkan 5 subjek lain mendapat terapi glukokortikoid pada saat berusia lebih dari satu tahun. Glukokortikoid yang diberikan pada subjek berupa hidrokortison dengan dosis yang

Tabel 2. Karakteristik pertumbuhan subjek penelitian

\begin{tabular}{lccc}
\hline Karakteristik & Rerata $(\mathrm{SB})$ & Median & Rentang \\
\hline Tinggi badan aktual SDS & $-0,12(1,29)$ & $-0,13$ & $-2,97-1,88$ \\
Tinggi badan berdasarkan bone age SDS & $-3,55(1,05)$ & $-3,61$ & $-5,23-(-1,68)$ \\
Prediksi tinggi dewasa SDS & $-3,29(1,08)$ & $-3,40$ & $-5,1-(-1,22)$ \\
MPH SDS aktual & $-0,15(1,28)$ & $-0,15$ & $-2,99-1,85$ \\
\hline
\end{tabular}

SDS $=$ skor standar deviasi

Gambar 1). Subjek yang memiliki IMT $\geq$ P95 sesuai dengan obesitas (7/14), memiliki IMT $\geq$ P85 - <P95 sesuai dengan gizi lebih (2/14), dan IMT pada P5-P85 sesuai dengan gizi baik (5/14) (terlampir pada Gambar 2). Dua belas dari 14 subjek memiliki asupan nutrisi disesuaikan dengan luas permukaan tubuh, keadaan klinis, kadar 17-OHP dan kadar testosteron. Rerata luas permukaan tubuh subjek penelitian adalah 1,25 $(0,91-1,67) \mathrm{m}^{2}$. Berdasarkan luas permukaan tubuh, kisaran dosis glukokortikoid yang diberikan adalah 
Tabel 3. Karakteristik tingkat maturasi tulang subjek penelitian

\begin{tabular}{lccc}
\hline Karakteristik & Rerata $(\mathrm{SB})$ & Median & Rentang \\
\hline Rentang usia tulang (tahun) & $7,3-11,3(1,69)$ & $7,1-11,1$ & $5-15,1$ \\
Usia tulang (tahun) & $13,3(1,97)$ & 13,3 & $10-17$ \\
Maturasi (\%) & $92,7(6,27)$ & 93 & $78,4-99$ \\
Advance (tahun) & $1,97(1,67)$ & 2,1 & $0-5,5$ \\
\hline
\end{tabular}

Tabel 4. Karakteristik terapi subjek penelitian

\begin{tabular}{lccc}
\hline Karakteristik & Rerata $(\mathrm{SB})$ & Median & Rentang \\
\hline Dosis glukokortikoid/LPB/hari $\left(\mathrm{mg} / \mathrm{m}^{2} /\right.$ hari) & $17,1(5,7)$ & 18,12 & $5,93-25$ \\
Dosis mineralokortikoid (mcg/hari) & $90(46,3)$ & 100 & $50-200$ \\
Durasi terapi (tahun, bulan) & $8,07(1,37)$ & 8,1 & $5,1-9,9$ \\
Kadar 17-OHP (nmol/L) & $166,9(293,4)$ & 17,8 & $0,2-876$ \\
\hline
\end{tabular}

5,93-25 mg/m²/hari, dengan rerata $17,1 \mathrm{mg} / \mathrm{m}^{2} /$ hari (SD 5,7), dan median $18,12 \mathrm{mg} / \mathrm{m}^{2} /$ hari. Tiga subjek pernah berhenti pengobatan dengan durasi waktu bervariasi 1-3 tahun (subjek 5, 8, dan 13).

Seluruh subjek mendapat pengobatan steroid dengan ketepatan waktu minum obat yang bervariasi, tidak ada subjek yang disiplin tepat waktu dalam minum obat (Tabel 4).

Seluruh subjek penelitian (14/14) tidak memiliki kepatuhan terapi yang baik. Tidak ada subjek yang kontrol teratur setiap 3 bulan sepanjang pengobatan, tidak ada subjek yang mengonsumsi glukokortikoid dan mineralokortikoid tepat waktu. Seluruh subjek penelitian pernah tidak meminum obat dalam jangka waktu pendek akibat keterbatasan terapi. Tidak satupun subjek yang memeriksakan 17-OHP setiap 3 bulan dan bone age setiap tahun untuk evaluasi terapi.

\section{Pembahasan}

Berdasarkan tinggi badan aktual, 13 dari 14 subjek memiliki perawakan normal dan satu perawakan pendek $(<\mathrm{P} 3)$. Subjek tersebut memiliki kecepatan pertumbuhan dan usia tulang normal, tinggi badan orang tuanya $<\mathrm{P} 3$ sehingga sesuai dengan diagnosis familial short stature. Tinggi badan 11 subjek berdasarkan usia tulang $<$ P3. Hal tersebut menunjukkan subjek termasuk berperawakan pendek dibandingkan populasi anak pada umumnya. Subjek mengalami percepatan pertumbuhan linear dan sesuai dengan keadaan undertreatment. Prediksi TB dewasa berdasarkan bone age accelerated menunjukkan subjek HAK akan memiliki perawakan pendek saat dewasa.
Anak dengan HAK memiliki kecenderungan IMT berlebih karena rasio massa lemak dibanding masa bebas lemak yang lebih tinggi dibandingkan anak normal. Konsumsi glukokortikoid menyebabkan retensi air dan meningkatkan nafsu makan. ${ }^{9}$ Finkielstain $\mathrm{dkk}^{10}$ melaporkan $35 \%$ anak HAK mengalami obesitas. Penelitian ini menunjukkan 7 dari 14 subjek (50\%) mengalami obesitas, angka ini lebih tinggi dibandingkan penelitian lain. Penelitian yang dilakukan di senter pendidikan yang sama melaporkan prevalensi obesitas $18,4 \% .^{11}$

Faktor risiko obesitas bersifat multifaktorial, di antaranya asupan diet, efek samping terapi, komplikasi penyakit, lingkungan keluarga (pendidikan, pendapatan orangtua, obesitas pada orangtua)..$^{12}$ Sembilan dari 14 kasus HAK penelitian ini berasal dari keluarga dengan tingkat pendapatan orang tua menengah ke atas. Hasil analisis diet menunjukkan 12/14 kasus memiliki asupan kalori yang berlebih (>100\%). Susanti ${ }^{11}$ melaporkan $61,3 \%$ pasien HAK obesitas memiliki asupan nutrisi lebih dan 57,1\% memiliki aktivitas fisis tidak aktif. Durasi terapi glukokortikoid berkorelasi sedang $(r=0,668 ; p=0,000)$ dengan indeks massa tubuh (IMT), dan dosis terapi glukokortikoid tidak menunjukkan korelasi dengan IMT.

Pubertas prekoks disebabkan oleh sekresi androgen adrenal berlebihan yang merupakan penanda keterlambatan diagnosis dan ketidakteraturan pengobatan. Pasien yang mendapat terapi pada usia $>1$ tahun juga memiliki risiko untuk terjadi pubertas prekoks. ${ }^{13,14}$ Perkembangan pubertas pada subjek penelitian berdasarkan Tanner diperlihatkan keadaan yang prekoks. Tanda pubertas sudah muncul lebih dini dibandingkan pada anak perempuan atau laki-laki 
pada umumnya, menggambarkan subjek mengalami undertreatment.

Data kadar hormon subjek penelitian menggambarkan kesesuaian dengan tahapan pubertas subjek penelitian secara garis besar. Kadar FSH dan LH yang rendah pada subjek no. 11 sesuai dengan keadaan subjek yang belum pubertas (A1M1P1). Kadar LH rendah pada 3 subjek perempuan $(2,6$, dan 10$)$ kemungkinan disebabkan oleh pengaruh waktu pengambilan darah, teknik pengambilan, dan keadaan hormonal subjek sendiri. Keadaan hormonal subjek perempuan dipengaruhi oleh siklus menstruasi (fase folikular, fase proliferasi dan fase luteal). Pengambilan darah pada subjek perempuan tidak disesuaikan dengan keadaan fase menstruasi masing-masing disebabkan keterbatasan waktu dan kehadiran subjek.

Kadar testosteron dapat dijadikan acuan untuk memperlihatkan kontrol metabolik pasien HAK. Lima dari 14 subjek penelitian memiliki kadar testosteron yang sangat tinggi dan 1 subjek memiliki kadar testosteron lebih dari 10 kali nilai normal. Kadar testosteron berkorelasi dengan kadar 17-OHP. Kadar testosteron yang sangat tinggi menunjukkan terapi yang diberikan pada subjek kurang (undertreatment). Namun, keadaan undertreatment tidak dapat dijadikan patokan hanya berdasarkan pemeriksaan kadar 17OHP sesaat. Pemeriksaan kadar hormon dilakukan 1 kali dan sewaktu sehingga kadar hormon masih mungkin dipengaruhi teknik pengambilan darah, waktu pengambilan darah, dan kondisi tiap subjek yang berbeda.

Dosis glukokortikoid sudah sesuai dengan panduan pengobatan HAK yang berlaku. Namun, secara klinis, laboratoris dan radiologi subjek sesuai dengan undertreatment. Penilaian dosis terapi untuk menentukan undertreatment atau pernah undertreatment tidak dapat dinilai dengan satu kali pemeriksaan tetapi diperlukan pemantauan dosis sebelumnya. Dosis terapi pada tiap kasus bersifat individu dan harus disesuaikan dengan perkembangan pubertas, pertumbuhan linear, kadar hormon dan usia tulang. Dosis mineralokortikoid yang diberikan sesuai dengan dosis yang dianjurkan yaitu 50$200 \mathrm{mcg} / \mathrm{hari}$, dan dosis tersebut tidak berbeda dengan penelitian yang lain. ${ }^{5-17}$

Waktu pemberian terapi masih menjadi kontroversi, sebagian penelitian melaporkan usia diagnosis dan terapi sejak dini akan memberikan luaran yang lebih baik terhadap tinggi badan dewasa akhir, tetapi penelitian lain melaporkan tidak adanya hubungan antara usia dimulainya terapi dengan luaran TB. Hal ini menunjukkan bahwa tiap individu mempunyai variasi percepatan pertumbuhan yang berbeda-beda. Pada dua tahun pertama dan pada saat masa pubertas, pemantauan terapi merupakan hal penting yang dilakukan untuk penyesuaian dosis terapi. ${ }^{6}$

Pemberian terapi glukokortikoid pada HAK tidak selalu dipantau dengan pemeriksaan 17-OHP karena keterbatasan fasilitas dan biaya. Penyesuaian dosis glukokortikoid seringkali didasarkan pada adanya gejala klinis virilisasi seperti pertambahan tinggi badan secara cepat, warna kulit semakin gelap, tumbuh atau bertambahnya rambut pubis dan aksila, dan munculnya tanda pubertas sebelum waktunya. ${ }^{3,8}$ Semua pasien HAK tidak memiliki keteraturan pengobatan. Mereka tidak datang teratur tiap 3-6 bulan. Selain itu, mereka juga tidak rutin memeriksakan kadar 17-OHP dan bone age. Pemeriksaan kadar 17-OHP pada pasien HAK sebaiknya dikerjakan pada minggu pertama kelahiran kemudian setiap 1-2 bulan, setiap 3 bulan selama masa kanak, dan setiap 4 bulan selama masa pubertas. Pemeriksaan bone age seharusnya dikerjakan satu kali per tahun untuk menilai tingkat maturasi tulang. Penilaian parameter klinis seperti pertumbuhan, tanda kelebihan hormon androgen, dan bone age menjadi penunjang optimal atau tidaknya terapi yang diberikan. ${ }^{18}$ Ketersediaan pemeriksaan penunjang dan keterbatasan biaya merupakan hambatan terbesar penyebab pemeriksaan ini tidak dikerjakan secara rutin.

Penelitian ini membuktikan undertreatment memicu terjadinya pubertas prekoks dan perawakan pendek pada kasus HAK. Edukasi keteraturan terapi pada orangtua dan subjek HAK yang beranjak dewasa sangat diperlukan untuk mencapai efektivitas terapi. Pemantauan pertumbuhan linier dapat dilakukan dengan pengukuran tinggi badan dan berat badan. Pertumbuhan linear merupakan parameter objektif sederhana untuk menilai pertumbuhan optimal dan efektivitas terapi yang diberikan pada pasien HAK terutama pada fasilitas terbatas yang tidak dapat menyediakan pemeriksaan 17-OHP dan bone age. Pemantauan terapi harus dilakukan tiap 3 bulan yaitu pengobatan, tumbuh kembang, komplikasi dan efek samping pengobatan. Edukasi kewaspadaan dalam mengenali gejala dan tata laksana awal HAK pada tenaga medis merupakan hal yang penting. Pemeriksaan fisis pada bayi baru lahir harus dilakukan sebagai upaya deteksi dini pasien HAK. 


\section{Kesimpulan}

Sebagian besar subjek mendapatkan undertreatment sehingga memiliki bone age accelerated dengan estimasi tinggi badan dewasa pendek. Pubertas prekoks dialami oleh sebagian besar subjek. Pemberian glukokortikoid dengan dosis yang direkomendasikan. Ditemukan ketidakteraturan pengobatan dan pemantauan yang buruk.

\section{Daftar pustaka}

1. American Academy of Pediatrics. Technical report: congenital adrenal hyperplasia. Pediatrics 2000;106:15118.

2. Bonfig W, Bechtold S, Schmidt H, Knorr D, Schwarz HP. Reduced final height outcome in congenital adrenal hyperplasia under prednisone treatment: deceleration of growth velocity during puberty. J Clin Endocrinol Metab 2007;92:1635-9.

3. Pulungan AB, Siregar CD, Aditiawati, Soenggoro EP, Triningsih E, Suryawan IWB, dkk. Korteks adrenal dan gangguannya. Dalam: Batubara JRL, Tridjaja B, Pulungan $\mathrm{AB}$, penyunting. Buku ajar endokrinologi anak. Edisi ke-1. Jakarta: Badan Penerbit Ikatan Dokter Anak Indonesia;2010. h. 251-95.

4. Arlt W, Willis DS, Wild SH, Krone N, Doherty EJ, Hahner S, dkk. Health status of adults with congenital adrenal hyperplasia: a cohort study of 203 patients. J Clin Endocrinol Metab 2010;95:5110-21.

5. Bonfig W, Pozza SBD, Schmidt H, Pagel P, Knorr D, Schwarz HP. Hydrocortisone dosing during puberty in patients with classical congenital adrenal hyperplasia: an evidence-based recommendation. J Clin Endocrinol Metab 2009;94:3882-8.

6. Hargitai G, Solyom J, Battelino T, Lebl J, Pribilincova Z, Hauspie R, dkk. Growth pattern and final height in congenital adrenal hyperplasia due to classical 21-hydroxylase deficiency. Horm Res 2001;55:161-71.

7. Brook CGD. The management of classical congenital adrenal hyperplasia due to 21-Hydroxylase deficiency. Clin Endocrinol 1990;33:559-67.

8. Manoli I, Kanaka-Gantenbein Ch, Voutetakis A, Maniati-Christidi M, Dacou-Voutetakis C. Early growth, pubertal development, body mass index and final height of patients with congenital adrenal hyperplasia: factors influencing the outcome. Clin endocrinol 2002;57:66976.

9. Charmandari E, Weise M, Bornstein SR, Eisenhofer G, Keil MF, Chrousos GP, dkk. Children with classic congenital adrenal hyperplasia have elevated serum leptin concentrations and insulin resistance: potential clinical implications. J Clin Endocrinol Metab 2002;87:211420.

10. Finkielstain GP, Kim MS, Sinaii N, Nishitani M, Ryzin CV, Hill SC, dkk. Clinical characteristics of a cohort of 244 patients with congenital adrenal hyperplasia. J Clin Endocrin Metab 2012;97:1-10.

11. Susanti. Karakteristik anak hiperplasia adrenal kongenital terkait obesitas sebagai akibat dari penyakit dan terapi (tesis). Jakarta: FKUI, 2013.

12. Sjarif D. Obesitas pada anak dan permasalahannya. Dalam: Trihono P, Purnamawati S, Sjarif D, Hegar B, Gunardi H, Oswari $\mathrm{H}$, dkk, penyunting. Hot topics in pediatrics II Jakarta : Fakultas Kedokteran Universitas Indonesia RS. Dr. Ciptomangunkusumo; 2002.h.21934.

13. Carel JC, Leger J. Precocious puberty. N Engl J Med. 2008;358:2366-77.

14. Dattani MT, Tziaferi V, Hindmars PC. Evaluation of disordered puberty. Dalam: Brook CGD, Clayton P, Brown R, penyunting. Clinical Pediatric Endocrinology. Blackwell publishing. 2009.h.213-38.

15. Riepe FG, Krone N, Vierman M, Partsch CJ, Sippell WG. Management of congenital adrenal hyperplasia: results of the ESPE questionnaire. Horm Res. 2002;58:196-205.

16. White PC, Speiser PW. Congenital adrenal hyperplasia due to 21-hydroxylase deficiency. Endocr Rev 2000;21:24591.

17. Claude J. Congenital adrenal hyperplasia owing to 21-hydroxylase deficiency: growth, development, and therapeutic consideration. Endocrinology and metabolism Clinics of North America 2001;30:193206.

18. Dauber A, Kellogg M, Majzoub JA. Monitoring of therapy in congenital adrenal hyperplasia. Clin Chemist 2010;56:1245-51.

19. Gohlke B, Woelfle J. Growth and puberty in Germany children. Deutsch Arztebl Int 2009;106:377-82. 
Nurul Iman Nilam Sari dkk: Profil pubertas dan pertumbuhan linear pada HAK dalam pengobatan

Tabel. Karakteristik pubertas, kadar hormon, dan bone age subjek penelitian

\begin{tabular}{|c|c|c|c|c|c|c|c|c|c|c|c|c|c|c|c|c|c|}
\hline $\begin{array}{l}\text { No } \\
\text { Su } \\
\text { bje } \\
\text { k }\end{array}$ & Usia & $\begin{array}{l}\text { Tip } \\
\text { e } \\
\text { HA } \\
\text { K }\end{array}$ & ТВ & IMT & $\begin{array}{l}\text { Aks } \\
\text { ila }\end{array}$ & $\begin{array}{l}\mathrm{Pu} \\
\text { bis }\end{array}$ & $\begin{array}{l}\text { Gen } \\
\text { ital/ } \\
\text { Ma } \\
\text { mae }\end{array}$ & $\begin{array}{l}\text { Menarch } \\
\text { e/Sperma } \\
\text { che }\end{array}$ & & $\begin{array}{c}\underset{\mathrm{FSH}}{(\mathrm{mIU} / \mathrm{m}} \\
\mathrm{L})\end{array}$ & $\begin{array}{l}\mathrm{LH}(\mathrm{mIU} / \\
\mathrm{mL})\end{array}$ & Estradiol & $\begin{array}{l}\text { Testostero } \\
\mathrm{n}\end{array}$ & 17-OHP & $\begin{array}{l}\text { Bone age (usia } \\
\text { tulang (tahun)) }\end{array}$ & $\begin{array}{l}\text { Dosis } \\
\text { Terapi } \\
\text { (mg/lpb/ } \\
\text { hari) }\end{array}$ & Terapi \\
\hline 1 & 7 th $1 \mathrm{bl}$ & SW & P90 & $\geq \mathrm{P} 95$ & A1 & P2 & G2 & Sudah(6) & Prek & $16,07(\uparrow)$ & $1,91(\uparrow)$ & $21,2(\uparrow)$ & $158,7(\uparrow)$ & $32,4(\uparrow)$ & Accelerated (6) & 13.84 & $\begin{array}{l}\text { Under } \\
\text { treatment }\end{array}$ \\
\hline 2 & 7 th 4 bl & SW & P75-90 & P90-95 & $\mathrm{A} 1$ & P2 & M2 & Sudah(6) & Prek & $2,17(\mathrm{~N})$ & $0,26(\downarrow)$ & $21,9(\uparrow)$ & $40,96(\uparrow)$ & $876(\uparrow)$ & Accelerated (4) & 22.64 & $\begin{array}{l}\text { Under } \\
\text { treatment }\end{array}$ \\
\hline 3 & 7 th $11 \mathrm{bl}$ & sw & P90 & $\geq P 95$ & A1 & P3 & M3 & Sudah(7) & Prek & $1,22(\mathrm{~N})$ & $0,77(\mathrm{~N})$ & $106,1(\uparrow)$ & $<2,5(\mathrm{~N})$ & $14,7(\uparrow)$ & Accelerated (7) & 20.83 & $\begin{array}{l}\text { Under } \\
\text { treatment }\end{array}$ \\
\hline 4 & 8 th 8 bl & SW & $\mathrm{P} 10-25$ & P10-25 & A1 & P2 & M2 & Belum & Prek & $3,23(\mathrm{~N})$ & $0,76(\mathrm{~N})$ & $22,1(\mathrm{~N})$ & $12,44(\mathrm{~N})$ & $16,7(\uparrow)$ & Accelerated $(4,3)$ & 9.37 & $\begin{array}{l}\text { Under } \\
\text { treatment }\end{array}$ \\
\hline 5 & 8 th $11 \mathrm{bl}$ & sw & P97 & P85 & $\mathrm{A} 2$ & P2 & G3 & $\operatorname{Sudah}(7)$ & Prek & $2,64(\mathrm{~N})$ & $1,33(\mathrm{~N})$ & $22,2(\uparrow)$ & $213,2(\uparrow)$ & $3,3(\uparrow)$ & Accelerated $(4,4)$ & 18.32 & $\begin{array}{l}\text { Under } \\
\text { treatment }\end{array}$ \\
\hline 6 & 9 th $1 \mathrm{bl}$ & SW & P25-50 & P75-85 & $\mathrm{A} 1$ & P1 & M2 & Belum & Sesuai & $1,29(\mathrm{~N})$ & $<0,07(\downarrow)$ & $19,2(\mathrm{~N})$ & $<2,5(\mathrm{~N})$ & $54,1(\uparrow)$ & Average (1) & 16.67 & Optimal \\
\hline 7 & 9 th $1 \mathrm{bl}$ & SW & P50-75 & $\geq \mathrm{P} 95$ & $\mathrm{~A} 1$ & P2 & M2 & Belum & Prek & $8,71(\uparrow)$ & $5,96(\uparrow)$ & $59,5(\uparrow)$ & $18,31(\mathrm{~N})$ & $17,4(\uparrow)$ & Accelerated $(5,9)$ & 18.89 & $\begin{array}{l}\text { Under } \\
\text { treatment }\end{array}$ \\
\hline 8 & 9 th $3 \mathrm{bl}$ & SW & P10-25 & $\geq \mathrm{P} 95$ & $\mathrm{~A} 3$ & P3 & M3 & Sudah(6) & Prek & $7,87(\uparrow)$ & $3,99(\uparrow)$ & $37,8(\uparrow)$ & $77,46(\uparrow)$ & $80,5(\uparrow)$ & Accelerated $(4,75)$ & 21.36 & treatment \\
\hline 9 & 9 th $5 \mathrm{bl}$ & SV & P25-50 & P50-75 & A1 & P2 & M2 & Belum & Prek & $5,77(\mathrm{~N})$ & $2,83(\uparrow)$ & $85,6(\uparrow)$ & $<2,5(\mathrm{~N})$ & $18,3(\uparrow)$ & Accelerated $(2,6)$ & 17.93 & treatment \\
\hline 10 & 9 th $7 \mathrm{bl}$ & SW & $<\mathrm{P} 3$ & P50-75 & A2 & P2 & M2 & Belum & Sesuai & $0,37(\downarrow)$ & $<0,07(\downarrow)$ & $<11,8(\mathrm{~N})$ & $<2,5(\mathrm{~N})$ & $0,2(\mathrm{~N})$ & Average $(2,4)$ & 24.14 & Optimal \\
\hline 11 & 9 th $10 \mathrm{bl}$ & NK & P90 & $\geq \mathrm{P} 95$ & A1 & P1 & M1 & Belum & Belum & $1,29(\mathrm{~N})$ & $<0,07(\downarrow)$ & $18,1(\mathrm{~N})$ & $<2,5(\downarrow)$ & $0,4(\mathrm{~N})$ & Accelerated $(3,7)$ & 5.93 & $\begin{array}{l}\text { Under } \\
\text { treatment }\end{array}$ \\
\hline 12 & 10 th $2 \mathrm{bl}$ & SW & P50-75 & $\geq \mathrm{P} 95$ & A3 & P3 & M3 & Sudah & Prek & $7,4(\mathrm{~N})$ & $1,74(\mathrm{~N})$ & $41,6(\mathrm{~N})$ & $147,9(\uparrow)$ & $633(\uparrow)$ & Accelerated $(4,8)$ & 25.00 & $\begin{array}{l}\text { Under } \\
\text { treatment }\end{array}$ \\
\hline 13 & 12 th $5 \mathrm{bl}$ & sv & P25-50 & P75-85 & A4 & P5 & G5 & Sudah(8) & Prek & $2,12(\mathrm{~N})$ & $0,61(\mathrm{~N})$ & $28,6(\mathrm{~N})$ & $291,10(\uparrow)$ & $574(\uparrow)$ & Accelerated $(4,6)$ & 14.39 & $\begin{array}{l}\text { Under } \\
\text { treatment }\end{array}$ \\
\hline 14 & 13 th $1 \mathrm{bl}$ & SV & P25 & $\geq P 95$ & A2 & P4 & M4 & Sudah & Sesuai & $5,48(\mathrm{~N})$ & $4,36(\mathrm{~N})$ & $55,1(\mathrm{~N})$ & $<2,5(\mathrm{~N})$ & $15,7(\uparrow)$ & Average $(1,9)$ & 10.77 & Optimal \\
\hline
\end{tabular}
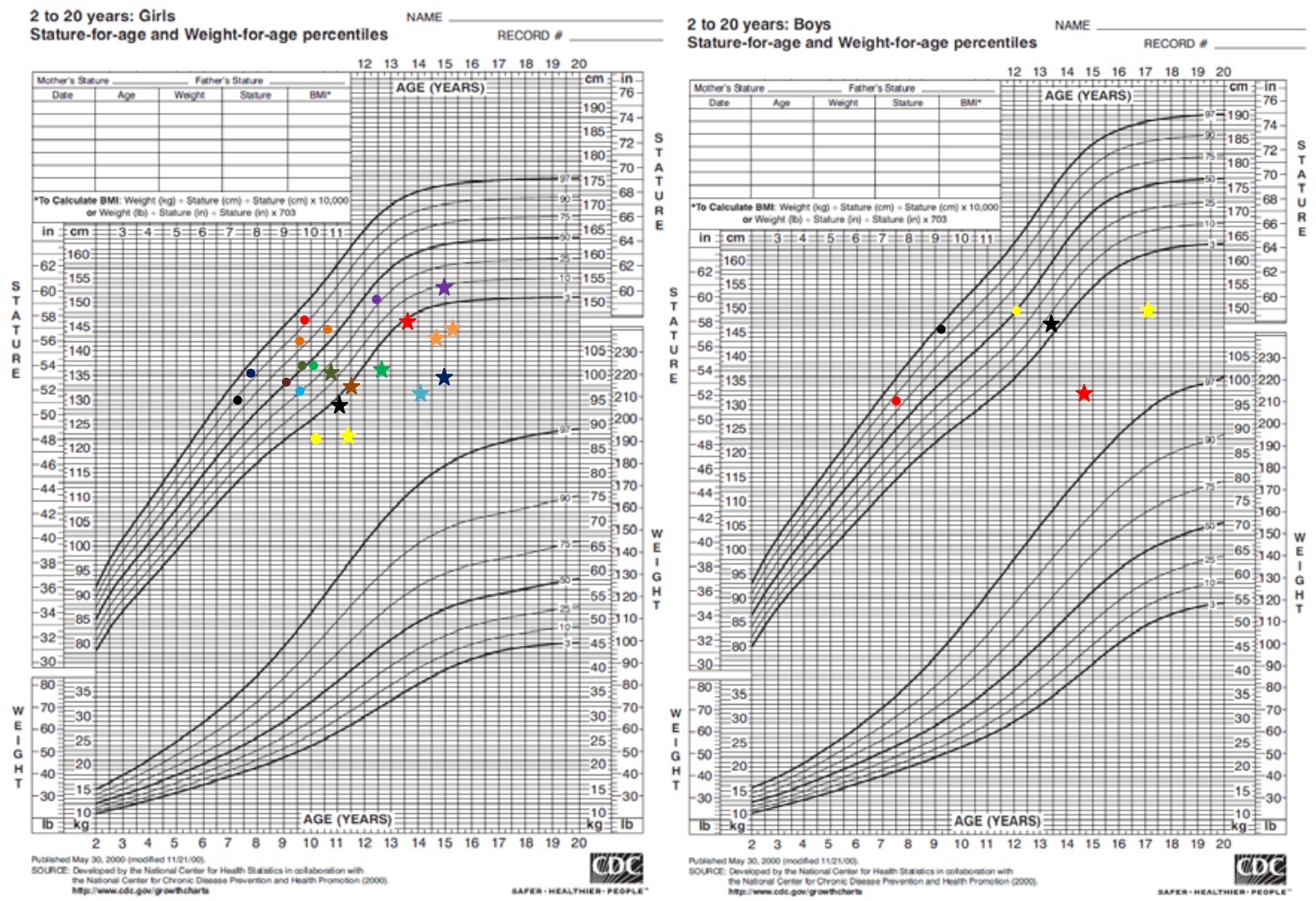

Gambar 1. Kurva tinggi badan aktual dan tinggi badan berdasarkan bone age penderita HAK

Keterangan $: 2 \bullet 3 \bullet 4 \bullet 6 \bullet 7 \bullet 8 \bullet 9 \bullet 10 \bullet 11 \bullet 12 \bullet 14 \bullet 1 \bullet 5 \bullet 13$

- = Tinggi badan aktual subjek, $\quad \star$ = Tinggi badan berdasarkan bone age accelerated 
Nurul Iman Nilam Sari dkk: Profil pubertas dan pertumbuhan linear pada HAK dalam pengobatan

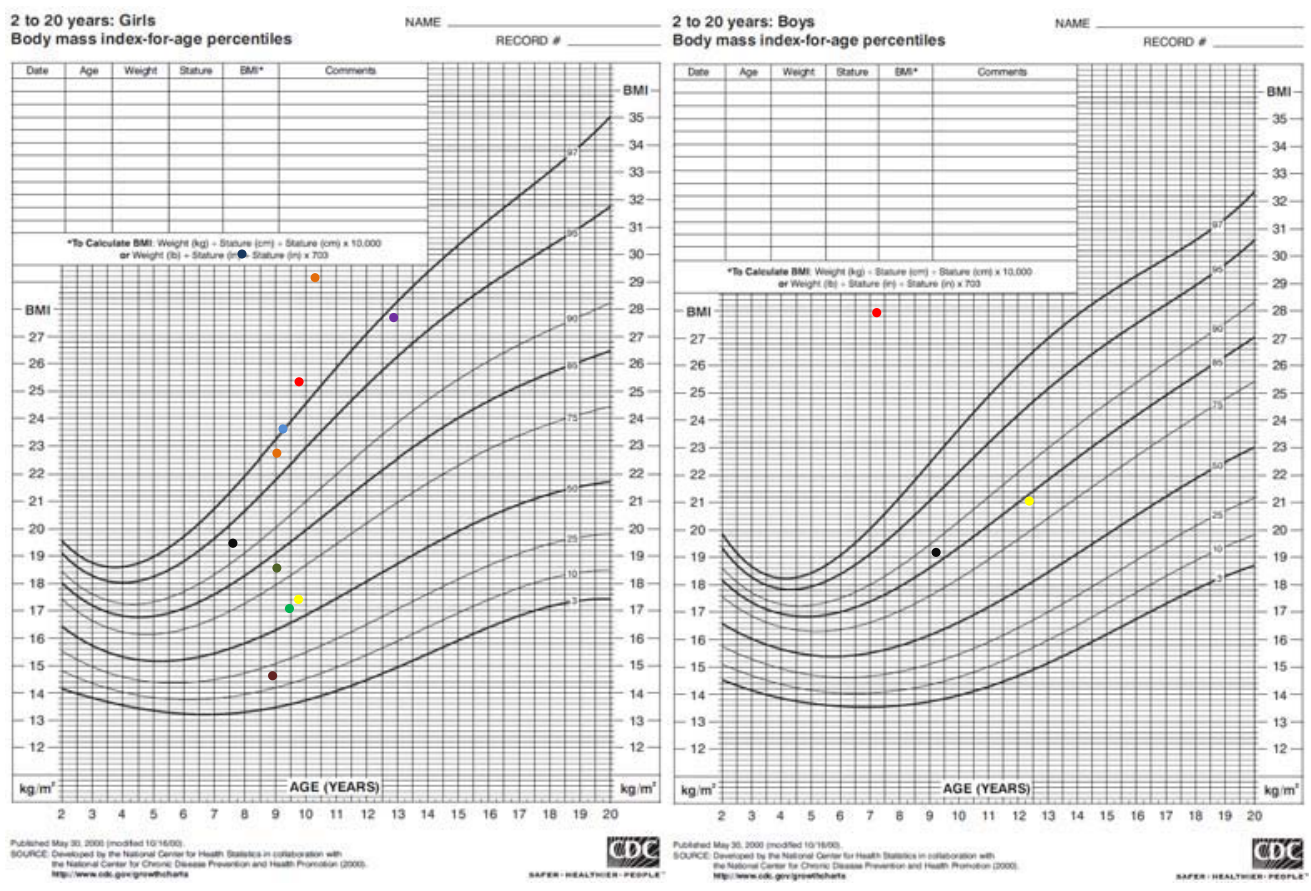

Gambar 2. Kurva IMT subjek penelitian

Keterangan: $2 \bullet 3 \bullet 4 \bullet 6 \bullet 7 \bullet 8 \bullet 9 \bullet 10 \bullet 11 \bullet 12 \bullet 14 \bullet 1 \bullet 5 \bullet 13$

- = Tinggi badan aktual subjek, $\quad \star$ = Tinggi badan berdasarkan bone age accelerated
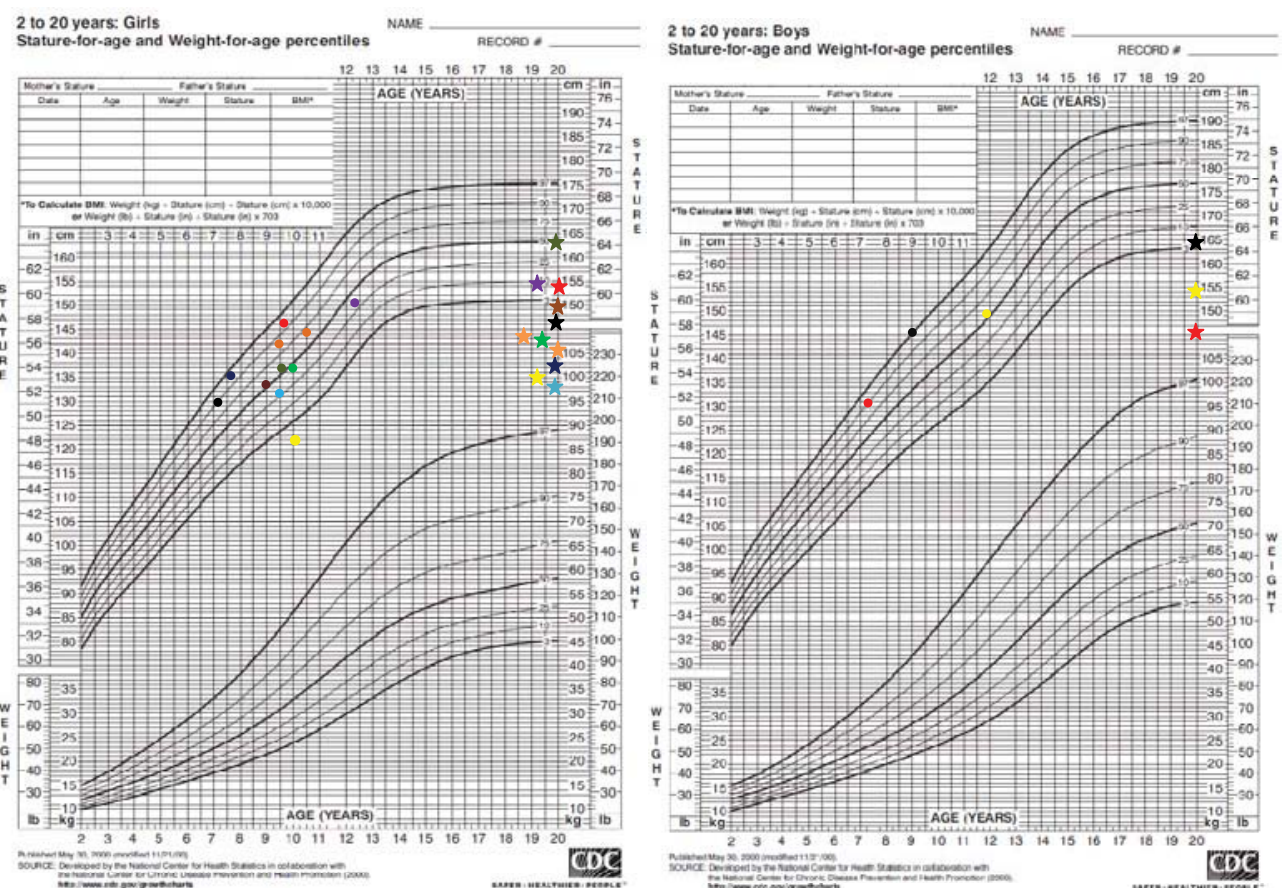

Gambar 3. Kurva tinggi badan aktual dan prediksi tinggi badan berdasarkan bone age penderita HAK Keterangan :

- = Tinggi badan aktual subjek, $\quad \star \quad$ = Prediksi tinggi badan dewasa 


\section{Perempuan}
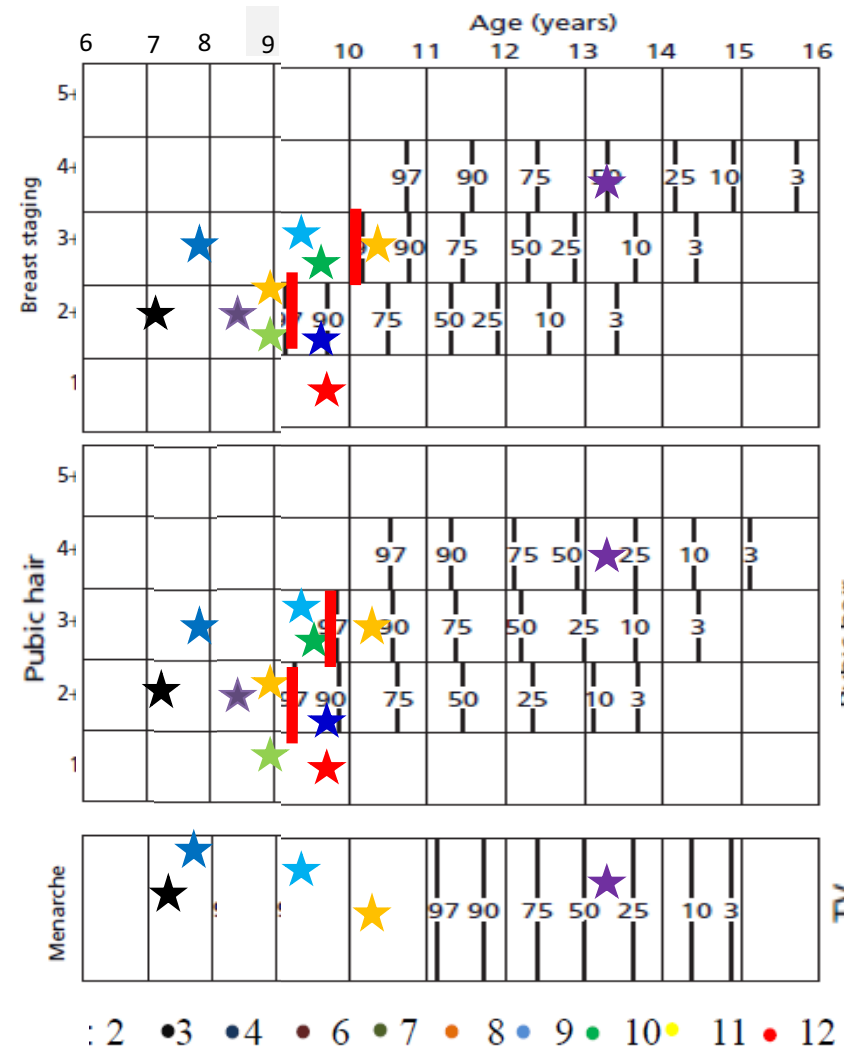
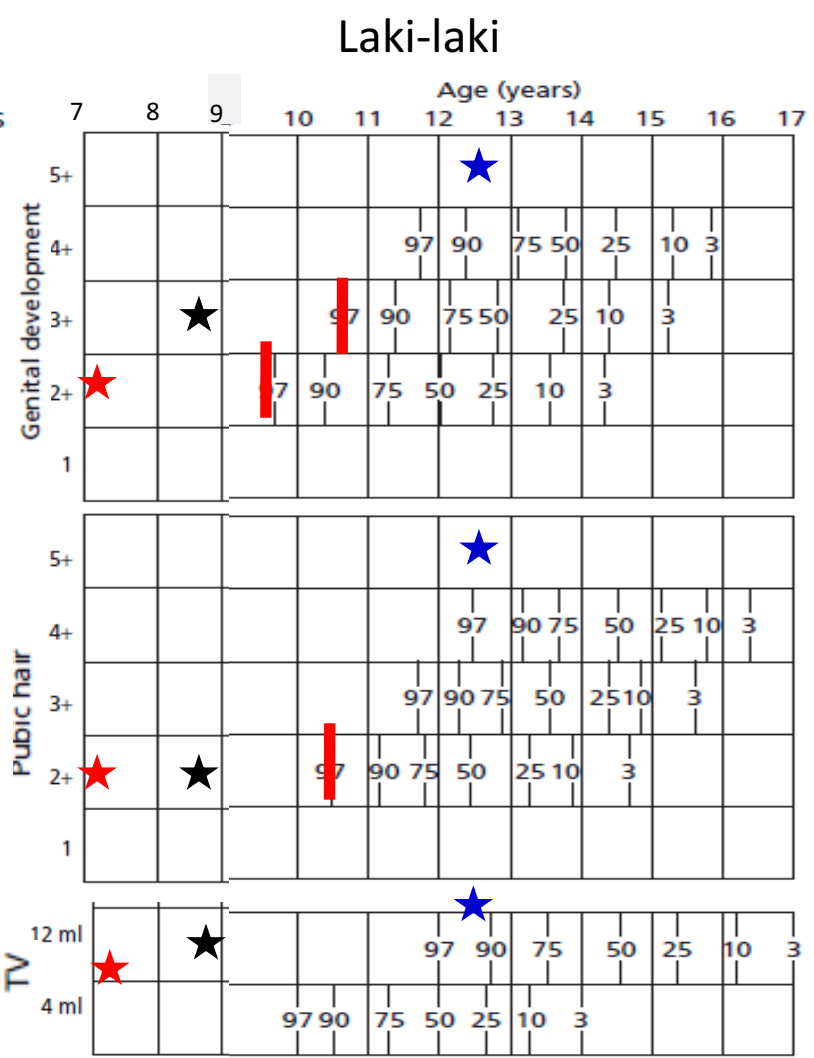

13

Gambar 4. Diagram pertumbuhan fisik subjek selama pubertas berdasarkan Tanner 